\title{
Association between col1a2 Polymorphism and the Occurrence of Pelvic Organ Prolapse in Brazilian Women
}

\section{Associação entre polimorfismo do gene col1a2 e a ocorrência do prolapso de órgãos pélvicos em mulheres brasileiras}

\author{
Josyandra Paula de Freitas Rosa ${ }^{1}$ Raphael Federicci Haddad ${ }^{1}$ Fabiana Garcia Reis Maeda ${ }^{1}$ \\ Ricardo Peres Souto ${ }^{1}$ Cesar Eduardo Fernandes ${ }^{1}$ Emerson de Oliveira ${ }^{1 \odot}$ \\ ${ }^{1}$ Faculdade de Medicina do ABC, Santo André, SP, Brazil \\ Address for correspondence Emerson de Oliveira, PhD, Av. Príncipe \\ Rev Bras Ginecol Obstet 2019;41:31-36. \\ de Galés, 821, 09060-650, Santo André, SP, Brazil . \\ (e-mail: emerson_oliveira@terra.com.br).
}

\section{Abstract \\ Keywords \\ - procollagen type I alpha $(\alpha) 2$ gene \\ - polymorphism \\ - pelvic organ prolapse}

\section{Resumo}

Objective To evaluate the rs 42524 polymorphism of the procollagen type I alpha ( $\alpha$ ) 2 (COL1A2) gene as a factor related to the development of pelvic organ prolapse (POP) in Brazilian women.

Methods The present study involved 112 women with POP stages III and IV (case group) and 180 women with POP stages zero and I (control group). Other clinical data were obtained by interviewing the patients about their medical history, and blood was also collected from the volunteers for the extraction of genomic DNA. The promoter region of the COL1A2 gene containing the rs 42524 polymorphism was amplified, and the discrimination between the $G$ and $C$ variants was performed by digestion of the polymerase chain reaction ( $P C R$ ) products with the MspA1l enzyme followed by agarose gel electrophoresis analysis.

Results A total of 292 women were analyzed. In the case group, 71 had the G/G genotype, 33 had the $G / C$ genotype, and 7 had the $C / C$ genotype. In turn, the ratio in the control group was $117 \mathrm{G} / \mathrm{G}, 51 \mathrm{G} / \mathrm{C}$, and $11 \mathrm{C} / \mathrm{C}$. There were no significant differences between the groups.

Conclusion Our data did not show an association between the COL1A2 polymorphism and the occurrence of POP.

Objetivo Avaliar o polimorfismo rs42524 do gene pró-colágeno tipo I alfa ( $\alpha$ ) 2 (COL1A2) como fator relacionado ao desenvolvimento de prolapso de órgãos pélvicos (POP) em mulheres brasileiras.

Métodos O estudo envolveu 112 mulheres com POP nos estádios III e IV (grupo caso) e 180 mulheres com POP nos estádios zero e I (grupo controle). Outros dados clínicos foram obtidos por meio de entrevistas com as pacientes sobre seu histórico médico, e o sangue das voluntárias também foi coletado para extração de DNA genômico. A região promotora do gene COL1A2 contendo o polimorfismo rs42524 foi amplificada, e a

(1) ORCID ID is https://orcid.org/0000-0002-5261-5563.

received

July 13, 2018

accepted

November 5, 2018
DOI https://doi.org/

10.1055/s-0038-1676599. ISSN 0100-7203.
Copyright $\odot 2019$ by Thieme Revinter

Publicações Ltda, Rio de Janeiro, Brazil
License terms

(c) (1) 
Palavras-chave

- gene pró-colágeno tipo I alfa $(\alpha) 2$

- polimorfismo

- prolapso de órgãos pélvicos discriminação entre as variantes $\mathrm{G}$ e $\mathrm{C}$ foi realizada por digestão dos produtos de reação em cadeia da polimerase (RCP) com a enzima MspA11, seguida de análise por eletroforese em gel de agarose.

Resultados Foram analisadas 292 mulheres. No grupo caso, 71 tinham o genótipo G/G, 33 tinham o genótipo $\mathrm{G} / \mathrm{C}$, e 7 tinham o genótipo $\mathrm{C} / \mathrm{C}$. Por sua vez, a relação no grupo controle foi de $117 \mathrm{G} / \mathrm{G}, 51 \mathrm{G} / \mathrm{C}$ e 11 C/C. Não houve diferenças significativas entre os grupos.

Conclusão Nossos dados não mostraram associação do polimorfismo do gene COL1A2 com a ocorrência de POP.

\section{Introduction}

Pelvic organ prolapse (POP) is a pathological condition characterized by the displacement of pelvic viscera in the caudal direction, towards the genital hiatus. The standardization of its symptoms was updated in 2016 by the International Continence Society (ICS) and by the International Urogynecology Association (IUGA). They considered the following complaints to be related to POP: vaginal bulging, pelvic or suprapubic pressure, bleeding, discharge and infections related to ulceration, need for manual maneuvers to facilitate defecation or urination, and pain in the sacral spine region. ${ }^{1}$

The prevalence of POP varies between 8 and 41\%, contributing substantially to the reduction of the quality of life of the patients, as they experience physical symptoms, but also to problems related to general health, personal relationships, and sexual function. ${ }^{2}$ In addition, POP is the main reason for surgery in aging women. ${ }^{3}$

The etiology of POP is considered multifactorial, and several risk factors, such as advanced age, pregnancy, obesity, neuropathies, ethnicity, hysterectomy, instrumental delivery, and menopause, have been identified. Recent evidence suggests the existence of a genetic component with a 3.2- to 2.4-fold increased risk for the mothers and sisters of affected women, respectively. The high prevalence of POP in patients with type I and III collagen disorders, such as Ehlers-Danlos and Marfan syndromes, corroborates the importance of studying the genetic background of patients with the disease.,

Older age and parity are the most significant etiological factors, but they do not fully explain the origin and progression of pelvic floor dysfunction in all women, since POP has been observed in nulliparous women and has been absent in many multiparous women. ${ }^{5}$ The main mechanism of pelvic floor dysfunction is the weakening of the structures that support the pelvic organs: connective tissue in the form of ligaments and endopelvic fascia, and the levator ani muscles. ${ }^{6}$

The main protein structure of connective tissues is type I collagen, a heterotrimer with two $\alpha-1$ chains and one $\alpha-2$ chain encoded by the procollagen type I alpha $(\alpha) 1$ (COL1A1) and procollagen type I alpha $(\alpha) 2$ (COL1A2) genes, respectively. This protein is physiologically important to support the pelvic floor structures and to confer mechanical stability to the genitourinary tract. ${ }^{7}$ The vaginal fascia and its liga- ments are formed predominantly by collagen type I and III, which enable the accommodation of the structures in cases such as sudden increased abdominal pressure and the passage of a fetus.

In the case of collagen changes, the pelvis becomes more susceptible to genital prolapse, as the fascia and its ligaments are put under stress during periods of increased intraabdominal pressure. Thus, it is believed that an abnormal connective tissue metabolism may be associated with this gynecological condition. $^{7}$

The COL1A2 gene is located on the chromosome $7 q 22.1 .^{8}$ It contains 52 exons and non-coding portions ( $38 \mathrm{~kb}$ in size). ${ }^{9}$ It encodes the procollagen alpha 2 chain, a component of the collagen type I molecule. ${ }^{10,11}$

Each $\alpha$-chain contains terminal propeptides in the $\mathrm{C}$ terminus (carboxy) and in the $\mathrm{N}$-terminus (amino), and a core domain composed of $338 \mathrm{Gly}-\mathrm{X}-\mathrm{Y}$ repeats, where $\mathrm{X}$ and Y exclude cysteine and tryptophan, and are often proline and hydroxyproline, respectively. Glycine, as the smallest amino acid, is the only residue capable of occupying the axial position of the triple helix, so that any change from a glycine residue will entail disruption of the helical structure. ${ }^{12,13}$

Genetic polymorphism is the presence of variation in the DNA sequence found at a frequency of $>1 \%$ of the population. A single-nucleotide polymorphism (SNP) is a site in the DNA where a single base pair or nucleotide varies from person to person. As genetic markers, SNPs can be used to track inheritance patterns of chromosomal regions from generation to generation. Although most of the polymorphisms are inactive, some may influence the promoter activity or the conformation of DNA and pre-mRNA, which may result in a change in the amino acid sequence and in the protein function and, therefore, in the phenotypic expression. ${ }^{6}$ The frequency of SNPs can be measured and has been associated with different risks of development of diseases. ${ }^{14}$

Mutations that affect the COL1A2 gene reduce the biosynthesis of type I collagen and, consequently, could be involved in osteogenesis imperfecta. ${ }^{15}$ According to the literature, a polymorphism of the COL1A2 is associated with vascular disease and osteoporotic fractures. ${ }^{16-18} \mathrm{~A}$ recent meta-analysis suggests that COL1A2 rs42524 is a significant risk factor for intracranial aneurysm susceptibility, with an especially strong effect in Asian people. ${ }^{19}$ However, in our review, it was not possible to find studies evaluating the relationship of this polymorphism with POP. 
Given the aging of the Brazilian population, which is estimated to be predominantly composed of adults and the elderly, according to the Brazilian Institute of Geography and Statistics (IBGE, in the Portuguese acronym), and considering the high morbidity of this gynecological condition and the high costs of its treatment, it can be concluded that POP is a highly relevant problem for the global public health. ${ }^{20,21}$

Thus, an important goal on the agenda of the urogynecological scientific community is to develop tools and markers capable of predicting which women will develop POP, so that they receive adequate follow-up, particularly in terms of obstetric care. For this purpose, the identification of genetic polymorphisms, more or less frequent in women with POP compared with the general population, can be the basis for an early disease risk assessment and is therefore extremely important.

Therefore, the objective of the present work is to verify the association between COL1A2 polymorphisms (rs42524) with POP.

\section{Methods}

This is a cohort study with a total of 292 postmenopausal women. The patients were treated at the Department of Urogynecology and Vaginal Surgery of the Department of Gynecology and Obstetrics of a School of Medicine. To ensure the rights and duties of the scientific community, of the study population and of the State, the present study complied with the guidelines of Resolution 196/96 of the National Health Council (CNS, in the Portuguese acronym) and, therefore, was previously submitted to evaluation and approval by the Research Ethics Committee of the Faculdade de Medicina do $\mathrm{ABC}$ (FMABC, in the Portuguese acronym) under the number 554.670/2014. All of the patients were informed about the study and signed a consent form for participation.

The inclusion criteria were: (1) diagnosis, by physical examination, of POP stages III and IV in the case group, and of POP stages zero and I in the control group; (2) a history compatible with postmenopause (absence of menstrual bleeding for at least a year); and (3) no hormone therapy in the previous 6 months for both groups.
The exclusion criteria were: (1) lack of permission from the patient to perform blood collection after having been informed about the study in both groups; and (2) patients who underwent any type of prior vaginal surgery in the control group.

In the medical interview, the following data were collected: age, ethnicity, body mass index (BMI), parity, place of birth and delivery route, obstetric interventions (analgesia and episiotomy), weight of the heaviest newborn, previous diseases (diabetes, hypertension, dyslipidemia, chronic cough, and constipation), life habits (physical activity with high physical exertion, and smoking), and previous hysterectomy.

All of the women were weighed and measured for the calculation of their BMI, followed by a gynecological examination, in which POP-Q staging was performed for the quantification of genital prolapse. ${ }^{22}$

For the extraction of genomic DNA, the illustra blood genomicPrep Mini Spin Kit (GE Healthcare Life Sciences, Chicago, IL, USA) was used, following the instructions of the manufacturer. The amplification reaction was performed in $20 \mu \mathrm{L}$ using an adequately diluted PCR Master Mix reagent (Promega Corporation, Madison, WI, USA) and the primers described by Liu et al (2012): ${ }^{23}$ 5'-TACCTGAGGCTTTGAGAC3' and 5'-GAAAATATAGAGTTTCCAGAG-3'. The amplification protocol was as follows: initial incubation at $94^{\circ} \mathrm{C}$ for 5 minutes followed by 45 cycles of 3 temperatures $\left(94^{\circ} \mathrm{C}\right.$ for 30 seconds, $49^{\circ} \mathrm{C}$ for 30 seconds, $72^{\circ} \mathrm{C}$ for 60 seconds) and a final incubation at $72^{\circ} \mathrm{C}$ for 10 minutes. The samples were then kept at $10^{\circ} \mathrm{C}$ until the electrophoresis was performed. The polymerase chain reaction (PCR) products were digested with the restriction endonuclease MspA1I for 16 hours and visualized on agarose gel stained with ethidium bromide. The genotypes were determined by the observed pattern of the digestion bands: a single 427 base pair (bp) for homozygous CC (mutant homozygous genotype); two bands of 312 and 115 bp for homozygous GG (wild type genotype), and three bands of 427, 312 and $115 \mathrm{bp}$ for heterozygous GC (mutant heterozygous genotype)(-Fig. 1).

The normality of the quantitative data was verified using the Shapiro-Wilk test. The qualitative variables were compared using the chi-squared and the Fisher exact tests. An unpaired t-test was used to compare the quantitative variables. The data were analyzed using GraphPad Prism 6.0 (GraphPad

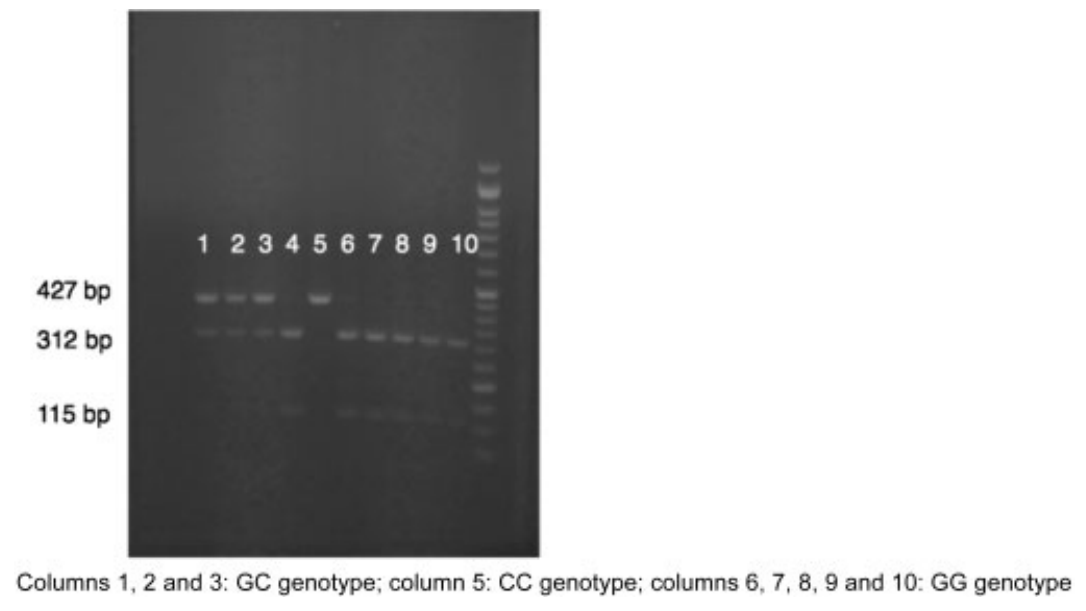

Fig. 1 Representative results for rs42524 genotyping of the COL1A2 gene. 
34 Association between col1a2 Polymorphism and the Occurrence of Pelvic Organ Prolapse Rosa et al.

Software, La Jolla, CA, USA) and IBM SPSS Statistics for Windows, Version 23.0 (IBM Corp., Armonk, NY, USA). After the stratification of the groups, the influence of the clinical characteristics on the risk of POP was estimated using odds ratios (ORs) obtained from the binary logistic regression model. The adopted significance level was 5\% ( $p<0.05)$, and the adopted confidence interval (CI) was $95 \%$.

\section{Results}

A total of 180 women with stage zero or I (control group) and 112 women with stage III or IV (case group) were selected for analysis. The groups were significantly different in terms of age, parity, number of pregnancies, and number of vaginal deliveries and home deliveries ( $\mathbf{- T a b l e ~} \mathbf{1}$ ).

The independent risk factors for the development of POP were determined by calculating the OR using the logistic regression model and are shown in - Table 2. Following the adjusted OR analysis, we found a statistical significance only for the variables age $\geq 51$ years old and home delivery.

There was a tendency for the Hardy-Weinberg equilibrium in both groups regarding the frequency of the genotypes studied $(p=0.046)$. We did not have DNA amplification in one patient in the case group and in another in the control group, totaling two cases of non-amplified DNA. Conversely, the presence or absence of COL1A2 gene polymorphisms was not associated with the presence of genital prolapse (-Table 3 ).

\section{Discussion}

The identification of patients who are susceptible to the development of POP may lead to preventive treatment. Several genetic studies have already been conducted, revealing different candidate genes and chromosomal loci that are associated with the risk of POP.

Pelvic organ prolapse affects negatively the quality of life of women, especially after the age of 50 years old; among these women, approximately $10 \%$ will require surgery by the age of 80 years old. The etiology of POP is multifactorial; of late, genetic factors have been extensively studied. ${ }^{10,11}$

Our results demonstrated a higher, albeit not statistically significant, prevalence of the COLIA2 polymorphism among patients with advanced POP. Genetic polymorphisms in the genes encoding $\alpha-1$ and $\alpha-2$ chains of type I collagen and its influence on POP were studied in the world literature. A Brazilian study demonstrated that there were no differences in the prevalence of the GT and TT genotypes of the COL1A1 gene between the groups even when we grouped patients with at least one polymorphic allele (GT and TT) and compared them with patients without the polymorphic allele (GG). Moreover, the COL1A1 Sp1-binding site was not significantly associated with genital prolapse among our study subjects. ${ }^{24}$ Another study of particular interest was the finding that the only case of polymorphic homozygosity (TT) of the COL1A1 gene was found in the control group (that is, women without POP), suggesting that the GT genotype has a stronger association with POP than the TT genotype. 25
Table 1 Analysis of the clinical characteristics of women with and without pelvic organ prolapse

\begin{tabular}{|c|c|c|c|}
\hline Variables & $\begin{array}{l}\text { Case group } \\
(n=112) \\
\text { mean or } \%\end{array}$ & $\begin{array}{l}\text { Control } \\
\text { group } \\
(n=180) \\
\text { mean or \% }\end{array}$ & $p$-value ${ }^{*}$ \\
\hline $\begin{array}{l}\text { Age, mean } \\
\text { (years old) }\end{array}$ & 68.4 & 57.8 & $<0.0001^{\mathrm{a}}$ \\
\hline White & $69.90 \%$ & $64.80 \%$ & \multirow[t]{2}{*}{$0.422^{b}$} \\
\hline Non-White & $30.10 \%$ & $35.20 \%$ & \\
\hline $\begin{array}{l}\text { Body mass index } \\
\left(\mathrm{kg} / \mathrm{m}^{2}\right)\end{array}$ & 28.8 & 28.9 & $0.874^{a}$ \\
\hline $\begin{array}{l}\text { Age of } \\
\text { menopause } \\
\text { (years old) }\end{array}$ & 48.8 & 46.6 & $0.07^{a}$ \\
\hline $\begin{array}{l}\text { Hormonal } \\
\text { therapy }\end{array}$ & $10.70 \%$ & $18.10 \%$ & $0.09^{b}$ \\
\hline Smoking & $13.10 \%$ & $20.10 \%$ & $0.15^{\mathrm{b}}$ \\
\hline $\begin{array}{l}\text { Arterial } \\
\text { hypertension }\end{array}$ & $57.80 \%$ & $49.40 \%$ & $0.186^{b}$ \\
\hline Diabetes mellitus & $24.50 \%$ & $23.70 \%$ & $0.888^{b}$ \\
\hline Dyslipidemia & $25.40 \%$ & $24.70 \%$ & $0.889^{b}$ \\
\hline Chronic cough & $1.80 \%$ & $6.80 \%$ & $0.08^{b}$ \\
\hline Constipation & $14.30 \%$ & $10.40 \%$ & $0.35^{\mathrm{b}}$ \\
\hline Pregnancy & 5.6 & 3.5 & $<0.0001^{\mathrm{a}}$ \\
\hline Parity & 4.8 & 2.9 & $<0.0001^{\mathrm{a}}$ \\
\hline Vaginal delivery & 4.1 & 2.3 & $<0.0001^{a}$ \\
\hline C-section & 0.08 & 0.12 & $0.377^{a}$ \\
\hline $\begin{array}{l}\text { Weight of the } \\
\text { heaviest } \\
\text { newborn (g) }\end{array}$ & 3,516 & 3,059 & $0.147^{a}$ \\
\hline Episiotomy & $8.30 \%$ & $9.20 \%$ & $>0.99^{b}$ \\
\hline Labor analgesia & $3.70 \%$ & $4.80 \%$ & $0.768^{b}$ \\
\hline Home birth & $25.90 \%$ & $3.05 \%$ & $<0.0001^{b}$ \\
\hline Hysterectomy & $15.20 \%$ & $15.60 \%$ & $>0.99^{b}$ \\
\hline $\begin{array}{l}\text { Exaggerated } \\
\text { physical exercise }\end{array}$ & $22.50 \%$ & $14.10 \%$ & $0.077^{b}$ \\
\hline
\end{tabular}

anpaired $\mathrm{t}$ test;

bisher exact test.

It has recently been shown that a common coding polymorphism (rs42524) in the COL1A2 gene, which replaces alanine for proline at position $\mathrm{Y}$ of the helical region of alpha 2 (I) collagen, could be a genetic risk factor for aneurysms. ${ }^{26}$ This study was followed by several others studying the association of this polymorphism with osteoporosis and vascular disease. Lindahl et al $(2009)^{18}$ showed that the heterozygote genotype had an increased risk of stroke, myocardial infarction, and lower bone mineral density. In turn, Majchrzycki et al (2017) ${ }^{17}$ found that the COL1A2 gene polymorphism may be a genetic risk factor related to the development of osteoporosis; and, lastly, Meng et al (2017) ${ }^{16}$ observed in a meta-analysis that rs42524 in the COL1A2 gene 
Table 2 Logistic regression of factors associated with the risk of pelvic organ prolapse

\begin{tabular}{|l|l|l|l|}
\hline Factors & $\begin{array}{l}\text { Crude OR } \\
(95 \% \mathrm{CI})\end{array}$ & $p$-value & $\begin{array}{l}\text { Adjusted OR } \\
(95 \% \mathrm{CI})\end{array}$ \\
\hline Age $\geq 51$ & $\begin{array}{l}15.57 \\
(4.73-51.2)\end{array}$ & $<0.0001$ & $\begin{array}{l}11.89 \\
(3.53-40)\end{array}$ \\
\hline Pregnancy $\geq 3$ & $\begin{array}{l}2.02 \\
(1.24-3.28)\end{array}$ & 0.004 & $\begin{array}{l}0.656 \\
(0.283-1.51)\end{array}$ \\
\hline Vaginal & 3.12 & $<0.0001$ & $\begin{array}{l}1.91 \\
(0.7-5.22)\end{array}$ \\
delivery $\geq 3$ & $(1.86-5.23)$ & & $\begin{array}{l}2.01 \\
(0.665-6.1)\end{array}$ \\
\hline Parity $\geq 3$ & 2.64 & $<0.0001$ & \\
\hline Home birth & $\begin{array}{l}11.62-4.31) \\
(4.14-29.7)\end{array}$ & $<0.0001$ & $\begin{array}{l}9.645 \\
(3.35-27.7)\end{array}$ \\
\hline
\end{tabular}

Abbreviations: $\mathrm{Cl}$, confidence interval; OR, odds ratio.

Table 3 Distribution of the frequencies of COL1A2 genotypes between cases and controls

\begin{tabular}{|c|c|c|c|}
\hline $\begin{array}{l}\text { COL1A2 } \\
\text { genotypes }\end{array}$ & $\begin{array}{l}\text { Case group } \\
(n=111)\end{array}$ & $\begin{array}{l}\text { Control group } \\
(n=179)\end{array}$ & $p$-value \\
\hline GG & 71 (63.9\%) & $117(65.3 \%)$ & \multirow[t]{3}{*}{$0.9705^{a}$} \\
\hline GC & 33 (29.7\%) & $51(28.5 \%)$ & \\
\hline $\mathrm{CC}$ & 7 (6.4\%) & $11(6.2 \%)$ & \\
\hline \multicolumn{4}{|l|}{$\begin{array}{l}\text { COL1A2 } \\
\text { aggregated } \\
\text { genotypes }\end{array}$} \\
\hline GG & 71 (63.9\%) & 117 (65.3\%) & \multirow[t]{2}{*}{$0.7105^{b}$} \\
\hline $\mathrm{GC}+\mathrm{CC}$ & 40 (36.1\%) & 62 (34.7\%) & \\
\hline
\end{tabular}

Abbreviations: CC, mutant homozygous genotype; GC, mutant heterozygous genotype; GG, wild type genotype.

${ }^{a}$ Chi-squared test;

${ }^{\mathrm{b}}$ Fisher exact test.

was associated with a significant increase in the risk of intracranial aneurysms in Japanese patients (allelic model: $\mathrm{OR}=1.94 ; 95 \% \mathrm{CI}: 1.03-3.64 ; p=0.04)$.

In our study, we investigated the possible association of the rs42524 polymorphism of the COL1A2 gene with the occurrence of POP. This is a pioneer work in the literature, and it failed to demonstrate the association of this polymorphism with POP.

We acknowledge that among the limitations of our work is the fact that our samples were not completely homogeneous in terms of some clinical characteristics, likely because advanced degrees of prolapse are more frequent in older women with more gestations and deliveries, who, in this case, correspond to those of the study group. Other limitations of our study are the fact that it only evaluated a single polymorphim and gene, as well as the miscegeneation of the Brazilian population, as well as the lack of equilibrium of Hardy-Weinberg. Regarding the latter, perhaps the small number of patients may be responsible for the absence of the genic equilibrium. In order to ensure that the genotyping was adequate, the PCR was always performed by the same three observers, and their consensus was recorded.

We believe that further studies that seek to establish genetic markers for POP are necessary and, therefore, the present study may be useful for future meta-analyses. We also think that we cannot extrapolate the conclusion for other populations based on these results. This study is specially important because the capacity to identify individuals at greater risk of developing POP through genetic screening could be useful in cases such as deciding the most appropriate delivery route for large fetuses.

Hopefully, focusing on the genetic susceptibility to POP will allow the stratification of risk for women who develop POP and thus establish strategies for its prevention and lifestyle changes. These interventions could reduce the need for corrective surgery and could improve the quality of life of women with the most severe stages of genital prolapse.

\section{Conclusion}

In conclusion, our data did not demonstrate an association between the COL1A2 polymorphism and the occurrence of POP.

\section{Acknowledgments}

The authors thank the FAPESP (Fundação deAmparo à Pesquisa do Estado de São Paulo) for financially supporting this research under contract 2014/01107-6.

\section{Contributors}

Rosa J. P. F., Haddad R. F., Maeda F. G. R., Souto R. P., Fernandes C. E. and Oliveira E. contributed with the project and the interpretation of data, the writing of the article, the critical review of the intellectual content, and with the final approval of the version to be published.

\section{Conflicts of Interest}

The authors have no conflicts of interest to declare.

\section{References}

1 Haylen BT, Maher CF, Barber MD, et al. An International Urogynecological Association (IUGA) / International Continence Society (ICS) Joint Report on the Terminology for Female Pelvic Organ Prolapse (POP). Neurourol Urodyn 2016;35(02):137-168. Doi: 10.1002/nau.22922

2 Lince SL, van Kempen LC, Vierhout ME, Kluivers KB. A systematic review of clinical studies on hereditary factors in pelvic organ prolapse. Int Urogynecol J Pelvic Floor Dysfunct 2012;23(10): 1327-1336. Doi: 10.1007/s00192-012-1704-4

3 Wang X, Li Y, Chen J, Guo X, Guan H, Li C. Differential expression profiling of matrix metalloproteinases and tissue inhibitors of metalloproteinases in females with or without pelvic organ prolapse. Mol Med Rep 2014;10(04):2004-2008. Doi: 10.3892/ mmr.2014.2467

4 Ferrari MM, Rossi G, Biondi ML, Viganò P, Dell'utri C, Meschia M. Type I collagen and matrix metalloproteinase 1, 3 and 9 gene polymorphisms in the predisposition to pelvic organ prolapse. Arch Gynecol Obstet 2012;285(06):1581-1586. Doi: 10.1007/ s00404-011-2199-9 
5 Swift SE, Pound T, Dias JK. Case-control study of etiologic factors in the development of severe pelvic organ prolapse. Int Urogynecol J Pelvic Floor Dysfunct 2001;12(03):187-192. Doi: 10.1007/ s001920170062

6 Bortolini MA, Rizk DE. Genetics of pelvic organ prolapse: crossing the bridge between bench and bedside in urogynecologic research. Int Urogynecol J Pelvic Floor Dysfunct 2011;22(10):1211-1219. Doi: 10.1007/s00192-011-1502-4

7 Skorupski P, Jankiewicz K, Miotła P, Marczak M, Kulik-Rechberger $\mathrm{B}$, Rechberger T. The polymorphisms of the MMP-1 and the MMP3 genes and the risk of pelvic organ prolapse. Int Urogynecol J Pelvic Floor Dysfunct 2013;24(06):1033-1038. Doi: 10.1007/ s00192-012-1970-1

8 de Wet W, Bernard M, Benson-Chanda V, et al. Organization of the human pro-alpha 2(I) collagen gene. J Biol Chem 1987;262(33): 16032-16036

9 Kataoka K, Ogura E, Hasegawa K, et al. Mutations in type I collagen genes in Japanese osteogenesis imperfecta patients. Pediatr Int 2007;49(05):564-569

10 De Vos A, Sermon K, Van de Velde H, et al. Two pregnancies after preimplantation genetic diagnosis for osteogenesis imperfecta type I and type IV. Hum Genet 2000;106(06):605-613. Doi: $10.1007 / \mathrm{s} 004390000298$

11 Alanay Y, Avaygan H, Camacho N, et al. Mutations in the gene encoding the RER protein FKBP65 cause autosomal-recessive osteogenesis imperfecta. Am J Hum Genet 2010;86(04): 551-559. Doi: 10.1016/j.ajhg.2010.02.022

12 Cole WG. The Nicholas Andry Award-1996. The molecular pathology of osteogenesis imperfecta. Clin Orthop Relat Res 1997;(343): 235-248

13 Byers PH, Wallis GA, Willing MC. Osteogenesis imperfecta: translation of mutation to phenotype. J Med Genet 1991;28(07): 433-442. Doi: 10.1136/jmg.28.7.433

14 Romero AA, Jamison MG, Weidner AC. Are single nucleotide polymorphisms associated with pelvic organ prolapse? J Pelvic Med Surg 2008;14(01):37-43. Doi: 10.1097/SPV.0b013e3181637a49

15 Gajko-Galicka A. Mutations in type I collagen genes resulting in osteogenesis imperfecta in humans. Acta Biochim Pol 2002;49 (02):433-441

16 Meng $\mathrm{Q}$, Hao $\mathrm{Q}$, Zhao $\mathrm{C}$. The association between collagen gene polymorphisms and intracranial aneurysms: a meta-analysis. Neurosurg Rev 2017;•.•;. Doi: 10.1007/s10143-017-0925-x
17 Majchrzycki M, Bartkowiak-Wieczorek J, Bogacz A, et al. The importance of polymorphic variants of collagen $1 \mathrm{~A} 2$ gene (COL1A2) in the development of osteopenia and osteoporosis in postmenopausal women. Ginekol Pol 2017;88(08):414-420. Doi: 10.5603/GP.a2017.0077

18 Lindahl K, Rubin CJ, Brändström $\mathrm{H}$, et al. Heterozygosity for a coding SNP in COL1A2 confers a lower BMD and an increased stroke risk. Biochem Biophys Res Commun 2009;384(04): 501-505. Doi: 10.1016/j.bbrc.2009.05.006

19 Gan Q, Liu Q, Hu X, You C. Collagen type I alpha 2 (COL1A2) Polymorphism contributes to intracranial aneurysm susceptibility: a meta-analysis. Med Sci Monit 2017;23:3240-3246. Doi: $10.12659 / \mathrm{msm} .902327$

20 Instituto Brasileiro de Geografia e Estatística. Fundo de População das Nações Unidas. Indicadores Sociodemográficos Prospectivos para o Brasil 1991-2030. Rio de Janeiro, RJ: Arbeit; 2006. http:// www.ibge.gov.br/home/estatistica/populacao/projecao_da_popu lacao/publicacao_UNFPA.pdf. Accessed July 22, 2017

21 Subak LL, Waetjen LE, van den Eeden S, Thom DH, Vittinghoff E, Brown JS. Cost of pelvic organ prolapse surgery in the United States. Obstet Gynecol 2001;98(04):646-651. Doi: 10.1016/ S0029-7844(01)01472-7

22 Bump RC, Mattiasson A, Bø K, et al. The standardization of terminology of female pelvic organ prolapse and pelvic floor dysfunction. Am J Obstet Gynecol 1996;175(01):10-17. Doi: 10.1016/S0002-9378(96)70243-0

23 Liu W, Pang B, Lu M, et al. The rs42524 COL1A2 polymorphism is associated with primary intracerebral hemorrhage in a Chinese population. J Clin Neurosci 2012;19(12):1711-1714. Doi: 10.1016/j.jocn.2012.03.025

24 Rodrigues AM, Girão MJ, da Silva ID, Sartori MG, Martins KdeF, Castro RdeA. COL1A1 Sp1-binding site polymorphism as a risk factor for genital prolapse. Int Urogynecol J Pelvic Floor Dysfunct 2008;19(11):1471-1475. Doi: 10.1007/s00192-0080662-3

25 Feiner B, Fares F, Azam N, Auslender R, David M, Abramov Y. Does COLIA1 SP1-binding site polymorphism predispose women to pelvic organ prolapse? Int Urogynecol J Pelvic Floor Dysfunct 2009;20(09):1061-1065. Doi: 10.1007/s00192-009-0895-9

26 Yoneyama T, Kasuya H, Onda H, et al. Collagen type I alpha2 (COL1A2) is the susceptible gene for intracranial aneurysms. Stroke 2004;35(02):443-448. Doi: 10.1161/01.STR.0000110788.45858.DC 